\title{
Assessment of natural radionuclides and its radiological hazards from tiles made in Nigeria
}

\author{
E.S. Joel ${ }^{\mathrm{a}, *}$, O. Maxwell ${ }^{\mathrm{a}}$, O.O Adewoyin ${ }^{\mathrm{a}}$, C.O Ehi-Eromosele ${ }^{\mathrm{b}}$, Z. Embong ${ }^{\mathrm{c}}$, M.A Saeed ${ }^{\mathrm{d}}$ \\ a Department of Physics, Covenant University Ota, Nigeria \\ ${ }^{\mathrm{b}}$ Department of Chemistry, Covenant University Ota, Nigeria \\ ${ }^{\mathrm{c}}$ Faculty of Applied Science and Teknologi Tun Hussein Onn, Malaysia Pagoh Campus. km 1, Jalan Panchor 84600, Muar, Johor, Malaysia \\ ${ }^{\mathrm{d}}$ Division of Science and Technology, University of Education Township, Lahore, Pakistan
}

\section{A R T I C L E I N F O}

\section{Keywords:}

Radioactivity concentrations

Radiological hazards

Tiles

\begin{abstract}
A B S T R A C T
Activity concentration of 10 different brands of tiles made in Nigeria were analyzed using High purity Germanium gamma detector and its hazard indices such as absorbed dose rate, radium equivalent activity, external Hazard Index (Hex), internal Hazard Index (Hin), Annual Effective Dose (mSv/y), Gamma activity Index (I $\gamma)$ and Alpha Index (I $\alpha)$ were determined. The result showed that the average activity concentrations of radionuclides $\left({ }^{226} \mathrm{Ra},{ }^{232} \mathrm{Th}\right.$ and $\left.{ }^{40} \mathrm{~K}\right)$ content are within the recommended limit. The average radium equivalent is within the recommended limit of $370 \mathrm{~Bq} / \mathrm{kg}$. The result obtained further showed that the mean values for the absorbed dose rate (D), external and internal hazard index, the annual effective dose (AEDR) equivalent, gamma activity index and Alpha Index were: $169.22 \mathrm{nGyh}^{-1}, 0.95$ and $1.14,1.59 \mathrm{mSv} / \mathrm{y}, 1.00 \mathrm{~Sv} \mathrm{yr}^{-1}$ and $0.34 \mathrm{re}^{-}$ spectively. The result established that radiological hazards such as absorbed dose rate, internal hazard, annual effective dose rate, gamma activity index and Alpha Index for some samples are found to be slightly close or above international recommended values. The result for the present study was compared with tiles sample from others countries, it was observed that the concentration of tiles made in Nigeria and other countries are closer, however recommends proper radiation monitoring for some tiles made in Nigeria before usage due to the long term health effect.
\end{abstract}

\section{Introduction}

The exposure of human beings to ionizing radiation from natural sources is a continuing and inescapable feature of life on earth. For most individuals, this exposure exceeds that from all man-made sources combined. There are two main contributors to natural radiation exposures: high-energy cosmic ray particles incident on the earth's atmosphere and radioactive nuclides that originated in the earth's crust and are present everywhere in the environment, including the human body itself (UNSCEAR, 2000). Many exposures to natural radiation sources are modified by human practices. In particular, natural radionuclides are released to the environment in mineral processing and uses, such as phosphate fertilizer production and use and fossil fuel combustion, causing enhanced natural radiation exposures (UNSCEAR, 2000). Natural radioactivity in soils comes from ${ }^{238} \mathrm{U}$ and ${ }^{232} \mathrm{Th}$ series and natural ${ }^{40} \mathrm{~K}$. Uranium occurs in minerals such as pitchblende, uraninite, etc. It is also found in phosphate rock, lignite and monazite sands. Radon is formed from the decay of radium. The interested radionuclides in the research about environmental radioactivity are ${ }^{226} \mathrm{Ra},{ }^{232} \mathrm{Th}$ and ${ }^{40} \mathrm{~K}$ (Ademola and Farai, 2006), among which ${ }^{226} \mathrm{Ra}$ is a radionuclide in the ${ }^{238} \mathrm{U}$ series and ${ }^{232} \mathrm{Th}$ is the first member in the ${ }^{232} \mathrm{Th}$ series. The natural radionuclides in building materials are responsible for the external and internal radiation exposures of individuals living in dwellings (Ali et al., 1996; Faheem et al., 2008; Ghosh et al., 2008; Turhan et al., 2008; Damla et al., 2011). Since the natural radionuclides are not uniformly distributed, the knowledge of the natural radioactivity in building materials is important for the determination of population exposure to radiation, as most of the residents spent $80-90 \%$ of their life time indoors ( $\mathrm{Lu}$, 2005; Lu and Zhang, 2008; Ghosh et al., 2008). Building materials are derived from both natural sources (e.g. rock and soil) and waste products (e.g. phosphogypsum, alum shale, coal flyash, oil shale ash, etc) and also from industry by-products (e.g. power plants, phosphate fertilizer and oil industry) (Baykara et al., 2011). The concentrations of ${ }^{226} \mathrm{Ra},{ }^{232} \mathrm{Th}$ and ${ }^{40} \mathrm{~K}$ in building materials such as tiles vary depending on the local geological and geographical conditions as well as geochemical characteristics of those materials

\footnotetext{
* Corresponding author.

E-mail address: emmanuel.joel@covenantuniversity.edu.ng (E.S. Joel).
} 
Table 1

Tiles of different types produced in Nigeria.

\begin{tabular}{lll}
\hline Sample name & Country & Sample size $(\mathrm{mm})$ \\
\hline BN Ceramics & Nigeria & $60 \times 60$ \\
PNT Ceramics & Nigeria & $30 \times 30$ \\
Golden Crown Ceramics & Nigeria & $25 \times 30$ \\
Royal Ceramics & Nigeria & $40 \times 40$ \\
Royal Crown & Nigeria & $30 \times 30$ \\
Goodwill Super Polish & Nigeria & $60 \times 60$ \\
NISPRO & Nigeria & $40 \times 40$ \\
Goodwill Vitrified & Nigeria & $40 \times 40$ \\
PNT Vitrified & Nigeria & $25 \times 40$ \\
Golden Crown & Nigeria & $30 \times 30$ \\
\hline
\end{tabular}

(Iqbal et al., 2000; Ghosh et al., 2008; Turhan et al., 2008). Therefore, it is important to measure the concentration of radionuclides in all the tiles used for building that was made in Nigeria and to estimate the radiological hazards to human health.

\section{Materials and methods}

\subsection{Preparation of samples}

10 samples of various tiles which were produced in Nigeria were used for this study. These tiles were purchased from Nigerian commercial market. This is shown in Table 1 with their sample names and ID (size). Initial labeling and cataloguing was done for easy identification. The tiles were broken into smaller pieces so as to allow further processing. All the samples were crushed using the Pascall Engineering Lab milling machine to pulverizable size. After each tile sample was crushed, the crusher or lab milling machine was thoroughly cleaned with high pressure blower (Wolf from Kango Wolf power tools, made in London, type 8793 and serial no: 978A) before the next sample was crushed. This whole process was repeated until all the samples were completely crushed into powder. The pulverizer used is the disk 'grinder/pulverizer' by Christy \& Norris Limited. After each pulverizing process, the machine was cleaned properly and blown with high pressure blower to avoid cross contamination of the samples. A very fine power was achieved from the pulverized samples, but for homogeneity, a $250 \mu \mathrm{m}$ sieve size was used and $1 \mathrm{~kg}$ of the sieved sample was weighed out. It was then placed in polythene nylon and labeled accordingly. High density polyethylene bottles (HDPB) were used to package the samples for radioactivity study. The bottles were washed with water and detergent and then rinsed six times with ordinary borehole water before finally rinsing with distilled water. The sieved samples of tiles that were contained in each bottle weighed $200 \mathrm{~g}$.

\subsection{Gamma spectrometric analysis of the selected samples}

The tiles produced in Nigeria of different brands was purchased from different suppliers, were prepared according to IAEA TRS-295 (IAEA, 1989). The samples were put in a plastic beaker container sealed for four (4) weeks secular equilibrium. Analysis of the samples were conducted in Canada (Activation Laboratory System) using High Purity Germanium detector, Canberra Lynx ${ }^{\mathrm{TM}}$ Digital Signal Analyzer (DSA), a $32 \mathrm{~K}$ channel integrated signal analyzer and a top-opening lead shield ( 4 " lead, copper/tin liner) to prevent high background counts with $50 \%$ relative efficiency and resolution of $2.1 \mathrm{keV}$ at $1.33 \mathrm{MeV}$ gamma energy of ${ }^{60} \mathrm{Co}$. The Genie-2K V3.2 software locates and analyzes the peaks, subtracts background, identifies the nuclides. The efficiency curves for this analysis were corrected for the attenuation and self-absorption effects of the emitted gamma photons. CAMET and IAEA standards (DL1a, UTS-2, UTS-4, IAEA-372 and IAEA-447) were used for checking the efficiency calibration of the system. For the activity measurements, the samples were counted for $86,400 \mathrm{~s}$ with the background counts
Table 2

Radioactivity concentration in tiles made in Nigeria in $(\mathrm{Bq} / \mathrm{kg})$.

\begin{tabular}{|c|c|c|c|c|}
\hline \multirow[t]{2}{*}{ Sample name } & \multirow[t]{2}{*}{ Sample size } & \multicolumn{3}{|c|}{ Activity concentration $(\mathrm{Bq} / \mathrm{kg})$} \\
\hline & & ${ }^{226} \mathrm{Ra}$ & ${ }^{232} \mathrm{Th}$ & ${ }^{40} \mathrm{~K}$ \\
\hline BN Ceramics & $60 \times 60$ & 37.5 & 101.5 & 670.0 \\
\hline PNT Ceramics & $30 \times 30$ & 241.0 & 77.5 & 510.0 \\
\hline Golden Crown Ceramics & $25 \times 30$ & 49.5 & 57.5 & 460.0 \\
\hline Royal Ceramics & $40 \times 40$ & 65.5 & 44.0 & 390.0 \\
\hline Royal Crown & $30 \times 30$ & 51.5 & 41.0 & 440.0 \\
\hline Goodwill Super Polish & $60 \times 60$ & 44.0 & 51.5 & 270.0 \\
\hline NISPRO & $40 \times 40$ & 59.5 & 461.0 & 860.0 \\
\hline Goodwill Vitrified & $40 \times 40$ & 70.5 & 445.5 & 540.0 \\
\hline PNT Vitrified & $25 \times 40$ & 35.5 & 346.5 & 370.0 \\
\hline Golden Crown & $30 \times 30$ & 27.0 & 113.0 & 390.0 \\
\hline Mean Value & & 68.2 & 173.9 & 490.0 \\
\hline
\end{tabular}

subtracted from the net count. The minimum detectable activity of the detector was determined with a confidence level of $95 \%$. The uncertainty errors were estimated keeping into account the associated errors from gamma courting emission probability and efficiency calibration standard of the system. The progeny of radium, ${ }^{214} \mathrm{Bi}$ and ${ }^{214} \mathrm{~Pb}$ emits gamma line $609 \mathrm{keV}, 934 \mathrm{keV}, 2204 \mathrm{keV}, 1764 \mathrm{keV}$ and $351 \mathrm{keV}$, $295 \mathrm{keV}$ were used but the resolution of radium was from the emission of $1764 \mathrm{keV}$ since it has low self-attenuation effect at high energy. Since ${ }^{232} \mathrm{Th}$ cannot be directly detected, the estimated activity via its progeny ${ }^{208} \mathrm{Tl}$ and ${ }^{228}$ Act using $2614.53 \mathrm{keV}$, (35.63\%) $583 \mathrm{keV}$ (30.3\%) and $911 \mathrm{keV}, 338 \mathrm{keV}, 463 \mathrm{keV}$. The gamma line of $1461 \mathrm{keV}(10.7 \%)$ was used to resolve ${ }^{40} \mathrm{~K}$.

\section{Result and discussions}

\subsection{Determination of radioactivity concentration}

Table 2 presents the radioactivity concentrations of ${ }^{226} \mathrm{Ra},{ }^{232} \mathrm{Th}$, and ${ }^{40} \mathrm{~K}$ for the tiles samples produced in Nigeria and their average value respectively. The observed activities concentration of the radionuclides content in the tiles ranged from 27 to $241 \mathrm{~Bq} / \mathrm{kg}$ for ${ }^{226} \mathrm{Ra}$, $41-461 \mathrm{~Bq} / \mathrm{kg}$ for ${ }^{232} \mathrm{Th}$ and $270-860 \mathrm{~Bq} / \mathrm{kg}$ for ${ }^{40} \mathrm{~K}$ respectively. The PNT ceramics tiles of size $30 \times 30 \mathrm{~mm}$ was noted to have the highest value of $241 \mathrm{~Bq} / \mathrm{kg}$ for ${ }^{226} \mathrm{Ra}$; NISPRO tile of size $40 \times 40 \mathrm{~mm}$ have $461 \mathrm{~Bq} / \mathrm{kg}$ for ${ }^{232} \mathrm{Th}$ and $860 \mathrm{~Bq} / \mathrm{kg}$ for ${ }^{40} \mathrm{~K}$ respectively. The lowest values of 27,41 and $270 \mathrm{~Bq} / \mathrm{kg}$ are found to be for tiles samples BN ceramics, Royal crown and Goodwill super polish while mean value of the radionuclides ${ }^{226} \mathrm{Ra},{ }^{232} \mathrm{Th}$, and ${ }^{40} \mathrm{~K}$ are $68.2,173.9$ and $490 \mathrm{~Bq} / \mathrm{kg}$ respectively. These average values were found to be within international reference value when compared with IAEA (2003) report. This present study was compared with others countries as reported elsewhere using the activity concentrations measured and are presented in Table 3. In contrast, it can be observed that the concentration of tiles in Nigeria and other countries are closer for ${ }^{226} \mathrm{Ra},{ }^{232} \mathrm{Th}$ and ${ }^{40} \mathrm{~K}$ radionuclides as reported by Amin and Naji (2013) except for ${ }^{40} \mathrm{~K}$ which is a little bit higher but still within the recommended value.

\subsection{Radiological assessment}

\subsubsection{The absorbed dose rate}

In this present study, the absorbed dose rates obtained from the calculated activity concentrations are shown in Table 4 . The total air absorbed dose rate received in an open air $1 \mathrm{~m}$ above the ground due to gamma emission from the radionuclides of ${ }^{226} \mathrm{Ra},{ }^{232} \mathrm{Th}$ and ${ }^{40} \mathrm{~K}$ in $\mathrm{BqKg}^{-1}$ available in an environment is calculated using Eq. (1) (UNSCEAR, 1998, 2000)

$D\left(n G y h^{-1}\right)=0.642 C_{R a}+0.604 C_{T h}+0.0417 C_{k} \angle 80 n G y h^{-1}$ 
Table 3

Comparison of Radioactivity concentration in tiles made in Nigeria with other tiles from other countries.

\begin{tabular}{|c|c|c|c|c|c|}
\hline Sample name & Country & ${ }^{226} \mathrm{Ra}$ & ${ }^{232} \mathrm{Th}$ & ${ }^{40} \mathrm{~K}$ & Reference \\
\hline BN Ceramics & Nigeria & 37.5 & 101.5 & 670.0 & Present study \\
\hline PNT Ceramics & Nigeria & 241.0 & 77.5 & 510.0 & Present study \\
\hline $\begin{array}{c}\text { Golden Crown } \\
\text { Ceramics }\end{array}$ & Nigeria & 49.5 & 57.5 & 460.0 & Present study \\
\hline Royal Ceramics & Nigeria & 65.5 & 44.0 & 390.0 & Present study \\
\hline Royal Crown & Nigeria & 51.5 & 41.0 & 440.0 & Present study \\
\hline $\begin{array}{l}\text { Goodwill Super } \\
\text { Polish }\end{array}$ & Nigeria & 44.0 & 51.5 & 270.0 & Present study \\
\hline NISPRO & Nigeria & 59.5 & 461.0 & 860.0 & Present study \\
\hline Goodwill Vitrified & Nigeria & 70.5 & 445.5 & 540.0 & Present study \\
\hline PNT Ceramics & Nigeria & 35.5 & 346.5 & 370.0 & Present study \\
\hline Golden Crown & Nigeria & 27.0 & 113.0 & 390.0 & Present study \\
\hline Taulell & Italy & 135 & 487 & 547 & $\begin{array}{l}\text { (Amin and Naji, } \\
\text { 2013) }\end{array}$ \\
\hline Cerypsa & Spain & 92.3 & 427 & 816 & $\begin{array}{l}\text { (Amin and Naji, } \\
\text { 2013) }\end{array}$ \\
\hline Alfujera & UAE & 60 & 13 & 463 & $\begin{array}{l}\text { (Amin and Naji, } \\
\text { 2013) }\end{array}$ \\
\hline Atlas & India & 452 & 227 & 237 & $\begin{array}{l}\text { (Amin and Naji, } \\
\text { 2013) }\end{array}$ \\
\hline Refan & Yemen & 125 & 21 & 376 & $\begin{array}{l}\text { (Amin and Naji, } \\
\text { 2013) }\end{array}$ \\
\hline Meran & China & 61 & 0 & 24 & $\begin{array}{l}\text { (Amin and Naji, } \\
\text { 2013) }\end{array}$ \\
\hline $\mathrm{Al}$ jouda & $\begin{array}{l}\text { Kingdom of } \\
\text { Saudi Arabia }\end{array}$ & $\mathbf{0}$ & 267 & 258 & $\begin{array}{l}\text { (Amin and Naji, } \\
\text { 2013) }\end{array}$ \\
\hline Roman & Indonesia & 114 & 47 & 223 & $\begin{array}{l}\text { (Amin and Naji, } \\
\text { 2013) }\end{array}$ \\
\hline
\end{tabular}

Table 4

The absorbed dose, radium equivalent (Raeq), external hazard index (Hex) and internal hazard index (Hin).

\begin{tabular}{|c|c|c|c|c|c|}
\hline Sample name & Sample size & $\begin{array}{l}\mathrm{Ra}_{\mathrm{eq}}(\mathrm{Bq} / \\
\mathrm{kg})\end{array}$ & $\mathrm{D}\left(\mathrm{nGyh}^{-1}\right)$ & $\mathbf{H}_{\mathrm{ex}}$ & $\mathbf{H}_{\text {in }}$ \\
\hline BN Ceramics & $60 \times 60$ & 234. 24 & 113.32 & 0.63 & 0.73 \\
\hline PNT Ceramics & $30 \times 30$ & 391.09 & 222.79 & 1.06 & 1.71 \\
\hline $\begin{array}{c}\text { Golden Crown } \\
\text { Ceramics }\end{array}$ & $25 \times 30$ & 167.15 & 85.69 & 0.45 & 0.59 \\
\hline Royal Ceramics & $40 \times 40$ & 158.45 & 84.89 & 0.43 & 0.61 \\
\hline Royal Crown & $30 \times 30$ & 144.01 & 76.18 & 0.39 & 0.53 \\
\hline Goodwill Super Polish & $60 \times 60$ & 138.44 & 70.61 & 0.37 & 0.49 \\
\hline NISPRO & $40 \times 40$ & 784.95 & 352.51 & 2.11 & 2.28 \\
\hline Goodwill Vitrified & $40 \times 40$ & 749.15 & 336.86 & 2.02 & 2.21 \\
\hline PNT Ceramics & $25 \times 40$ & 559.49 & 247.51 & 1.51 & 1.61 \\
\hline Golden Crown & $30 \times 30$ & 218.62 & 101.85 & 0.53 & 0.66 \\
\hline Mean Value & & 354.56 & 169.22 & 0.95 & 1.14 \\
\hline
\end{tabular}

Considering the absorbed dose rates presented in Table 4, it can be observed that the highest value of $352.51 \mathrm{nGyh}^{-1}$ was reported in NISPRO tiles whereas the lowest value of $70.61 \mathrm{nGyh}^{-1}$ was noted in Goodwill super polish tile. Comparing the absorbed dose rate in this present study with the standard value of $80 \mathrm{nGyh}^{-1}$ recommended by UNSCEAR (1998), the highest value obtained in this present study is higher by a factor of 4.4 .

\subsubsection{Determination of radium equivalent (Raeq)}

The level of radionuclides from ${ }^{226} \mathrm{Ra},{ }^{232} \mathrm{Th}$ and ${ }^{40} \mathrm{~K}$ in the analyzed building materials is non- uniformly distributed. The Raeq activity of the measured radionuclides is used to compare the activity of each of ${ }^{226} \mathrm{Ra},{ }^{232} \mathrm{Th}$ and ${ }^{40} \mathrm{~K}$ contents in the building materials. Raeq with unit as BqKg-1 was calculated using Eq. (2).

$R_{\text {aeq }}=A C_{R A}+1.43 C_{T h}+0.077 A C_{K}$

where $\mathrm{AC}_{\mathrm{RA}}, \mathrm{AC}_{\mathrm{Th}}$ and $\mathrm{AC}_{\mathrm{K}}$ are the activities concentration of ${ }^{226} \mathrm{Ra}$, ${ }^{232} \mathrm{Th}$ and ${ }^{40} \mathrm{~K}$ measured in $\mathrm{BqKg}^{-1}$ respectively. This radium equivalent activity defines the weighted sum of the individual activities of ${ }^{226} \mathrm{Ra},{ }^{232} \mathrm{Th}$ and ${ }^{40} \mathrm{~K}$ with the idea that for ${ }^{226} \mathrm{Ra}$, Raeq is $10 \mathrm{~Bq} / \mathrm{kg}$, for ${ }^{232} \mathrm{Th}$, Raeq is $7 \mathrm{~Bq} / \mathrm{kg}$ and for ${ }^{40} \mathrm{~K}$, Raeq is $130 \mathrm{Bqkg}^{-1}$. The maximum value of Raeq in tiles materials must be less than $370 \mathrm{~Bq} / \mathrm{kg}$ as recommended by UNSCEAR (1998) and UNSCEAR (2000). The radium equivalent activity values obtained from this present study varies from 138.44 to $784.95 \mathrm{BqKg}^{-1}$ with the highest value of $784.95 \mathrm{BqKg}^{-1}$ reported in NISPRO whereas the lowest value of $138.44 \mathrm{BqKg}^{-1}$ was noted in Goodwill super polish tile and the mean value of $354.56 \mathrm{BqKg}^{-1}$ is noted. It can be observed that some tiles samples such as PNT Ceramics $(30 \times 30)$, NISPRO, Goodwill Vitrified and PNT Ceramics $(25 \times 40)$ have the Raeq value that exceeds the recommended limit of $370 \mathrm{BqKg}^{-1}$ by UNSCEAR (1998) and UNSCEAR (2000) as presented in Table 4.

\subsubsection{Evaluation of external hazard index}

The gamma ray radiation hazards index due to the specified radionuclides were assessed by external radiation hazard and was calculated using Eq. (3) according to UNSCEAR (2000).

$H_{e x}=\left(C_{R a} / 370\right)+\left(C_{T h} / 259\right)+\left(C_{K} / 4810\right)$

where,

$C_{R a}, C_{T h}$ and $C_{K}$ are the average activity concentrations of ${ }^{226} \mathrm{Ra}$, ${ }^{232} \mathrm{Th}$ and ${ }^{40} \mathrm{~K}$ in $\mathrm{Bqkg}^{-1}$ respectively. For the radiation hazard to be acceptable, it is recommended that the Hex be less than unity. The estimated $\mathrm{H}_{\mathrm{ex}}$ for all the samples varies from 0.37 to 2.11 with highest value noted in NISPRO tile whereas the lowest value reported in Goodwill super polish. This highest value from the present study is higher than the recommended value of $\leq 1$ according to UNSCEAR (2000) by a factor of 5.7 .

\subsubsection{Determination of Internal Hazard Index}

The hazard which is defined in relation to internal hazard is represented by $\mathrm{H}_{\text {in }}$ respectively and can be determined using Eq. (4) (Beretka and Mathew, 1985):

$H_{\text {in }}=\left(C_{R a} / 185\right)+\left(C_{T h} / 259\right)+\left(C_{K} / 4810\right)$

where $C_{\mathrm{Ra}}, \mathrm{C}_{\mathrm{Th}}$ and $\mathrm{C}_{\mathrm{K}}$ are activity concentrations of ${ }^{226} \mathrm{Ra},{ }^{232} \mathrm{Th}$ and ${ }^{40} \mathrm{~K}$, respectively in $\mathrm{Bq} / \mathrm{kg}$. For the safe use of a building material such as tiles for decorative purposes in construction, $\mathrm{H}_{\text {in }}$ should be less than unity. The calculated values of $\mathrm{H}_{\text {in }}$ for tile samples used are shown in Table 4. The values ranged between 0.53 and 2.28 and the mean values of 1.14 for internal hazard $\left(\mathrm{H}_{\mathrm{in}}\right)$. The obtained results for $\mathrm{H}_{\mathrm{in}}$ for PNT ceramic, NISPRO, Goodwill super polish and PNT ceramic $(25 \times 40)$ tiles are above recommended limit of unity. The results for other tile samples are less than unity and are in agreement with the recommended international values.

\subsubsection{The annual effective dose rate}

The indoors annual effective dose equivalent received by human is estimated from the indoor internal dose rate (Din), occupancy factor which is defined as the level of human occupancy in an area in proximity with radiation source; is given as $80 \%$ of $8760 \mathrm{~h}$ in a year, and the conversion factor of $0.7 \mathrm{~Sv} \mathrm{~Gy}^{-1}$ which is used to convert the absorbed does in air to effective dose (UNSCEAR, 2000). The annual effective dose equivalent is estimated using Eq. (5).

$A E D R=\left(0.49 C_{R a}+0.76 C_{T h}+0.048 C_{K}\right) \times 8.76 \times 10^{-3}$

The value of the AEDE ranges from 0.65 to $3.69 \mathrm{mSv} \mathrm{y}^{-1}$ with a mean value of $1.59 \mathrm{mSv} \mathrm{y}^{-1}$. The mean values from the samples surpass the world's average value of $0.07 \mathrm{mSv} \mathrm{y}^{-1}$ by a factor 5.7. Details of all the samples are presented in Table 5.

\subsubsection{Gamma index determination (I $\gamma$ )}

Gamma index is used to evaluate the $\gamma$-radiation hazard related to the natural radionuclide in the particular samples under investigation. 
Table 5

The annual effective dose (mSv/y), gamma activity index (I $\gamma)$ and alpha index (I $\alpha)$.

\begin{tabular}{lllll}
\hline Sample name & Sample size & $\begin{array}{l}\text { Annual } \\
\text { effective dose } \\
(\mathrm{mSv} / \mathbf{y})\end{array}$ & $\begin{array}{l}\text { Gamma } \\
\text { activity index } \\
(\mathbf{I} \gamma)\end{array}$ & $\begin{array}{l}\text { Alpha } \\
\text { index (I } \boldsymbol{\alpha})\end{array}$ \\
\hline BN Ceramics & $60 \times 60$ & 1.12 & 0.76 & 0.19 \\
PNT Ceramics & $30 \times 30$ & 1.76 & 1.36 & 1.21 \\
Golden Crown & $25 \times 30$ & 0.79 & 0.61 & 0.25 \\
$\quad$ Ceramics & & & & \\
Royal Ceramics & $40 \times 40$ & 0.74 & 0.57 & 0.33 \\
Royal Crown & $30 \times 30$ & 0.68 & 0.52 & 0.26 \\
Goodwill Super & $60 \times 60$ & 0.65 & 0.49 & 0.22 \\
$\quad$ Polish & $40 \times 40$ & 3.69 & 2.79 & 0.29 \\
NISPRO & $40 \times 40$ & 2.84 & 0.18 & 0.35 \\
Goodwill & & & & \\
$\quad$ Vitrified & $25 \times 40$ & 2.61 & 1.97 & 0.18 \\
PNT Ceramics & $25 \times 30$ & 1.03 & 0.79 & 0.14 \\
Golden Crown & $30 \times 59$ & 1.00 & 0.34 \\
Mean Value & & 1.59 & & \\
\hline
\end{tabular}

The gamma index representation ( $\mathrm{\gamma} \gamma$ ) is estimated using Eq. (6) as presented by OECD (1979).

$I_{\gamma}=C_{R a} / 300(B q / k g)+C_{T h} / 200(B q / k g)+C_{K} / 3000(B q / k g)$

The estimated results are presented in Table 5. The controls on the radioactivity of building materials according to RP122 (EC, 1999) is based on the dose criterion for control and exemption. The dose effective exceeding the criterion level of $1 \mathrm{mSvy}^{-1}$ should be taken into account for radiation protection. It recommends that controls of dose range of $0.3-1 \mathrm{mSvy}^{-1}$, which is the excess gamma dose to that received outdoors. The gamma activity index is used to identify whether a dose criterion is met (EC, 1999). This gamma activity index accounts for the ways and amounts in which the materials used in building, with limit value of their indices not exceeding the recommended value and depends on the dose criterion shown in Table 5. In this present study, the dose has been calculated excluding the background dose which was shielded by the building materials when used in bulk but does not still exclude when building materials used as a superficial material. This is because the thin layers of superficial material do not reduce significantly the background dose. The gamma activity index $\leqslant 1$, corresponds to annual effective dose less than or equal to $1 \mathrm{mSvy}^{-1}$, while gamma activity index $\leqslant 0.5$ corresponds to $0.3 \mathrm{mSvy}^{-1}$ if the materials are used in bulk quantity. At the same time, gamma activity index $\leqslant 6$ corresponds to annual effective dose of $1 \mathrm{mSvy}^{-1}$ and gamma activity index $\leqslant 2$ corresponds to an annual effective dose $\leqslant 0.3 \mathrm{mSvy}^{-1}$ if the bulk materials are used in a superficial way. In this study as shown in Table 5, the results for superficial materials such as tiles vary from 0.18 $\mathrm{mSvy}^{-1}$ (Goodwill vitrified tile) to $2.79 \mathrm{mSvy}^{-1}$ (NISPRO tile) with average value of $1.00 \mathrm{mSvy}^{-1}$. Building materials such as tile should be exempted from all restrictions regarding radioactivity if the excess gamma radiation emanating from them increases the annual effective dose of a member public by $0.3 \mathrm{mSv}$ at the most. Considering the criterion of unity that corresponds to annual effective of $1 \mathrm{mSv}$, all the present values are below the criterion which corresponds to the protection level except PNT ceramic $(30 \times 30)$, NISPRO and PNT ceramic $(25 \times 40)$ tiles.

\subsubsection{Determination of alpha index (I $\alpha)$}

The assessment of the alpha index is another important aspect of hazard assessment that deals with the estimation of that excess alpha radiation due to radon inhalation originating from building materials. The alpha index calculated using Eq. (7) (Righi and Bruzzi, 2006; Xinwei et al., 2006) is:

$I_{\alpha}=C_{R a} / 200(B q / k g)$

where $\mathrm{C}_{\mathrm{Ra}}$ is the activity concentration of radium $\mathrm{Bqkg}^{-1}$ in building materials. If the radium activity level in building material exceeds the values of $200 \mathrm{Bqkg}^{-1}$ there is possibility that the radon exhalation from the material could cause indoor radon concentrations exceeding $\mathrm{Bqm}^{-3}$. Table 5 presents the values for alpha index. The International Commission on Radiation protection recommends an action level of $200 \mathrm{Bqm}^{-3}$ for radon in dwellings (ICRP, 1994). At the same time, if this radium activity level is below $100 \mathrm{Bqkg}^{-1}$, it shows that radon exhalation from building materials may not likely cause indoor concentration greater than $200 \mathrm{Bqm}^{-3}$ (Xinwei et al., 2006). It is reported that the recommended exempted value and the recommended upper limit for radon concentrations are $100 \mathrm{Bqkg}^{-1}$ and $200 \mathrm{Bqkg}^{-1}$ respectively in building materials (RPA, 2000). It is noted that the upper limit of radon concentration (I $\alpha$ ) is equal to 1 (Tufail et al., 2007). The results of the present study show that the radon concentration varies from 0.14 to 1.21 respectively with average value of 0.34 . With this lower value, it indicates that the radon exhalation from all the analyzed samples would cause indoor concentration lower than $200 \mathrm{Bqkg}^{-1}$.

\section{Conclusions}

The measurement of natural radioactivity concentration and its associated radiological risks from 10 investigated tiles samples made in Nigeria for buildings purposes were evaluated using gamma ray spectrometry. These following endpoints can be drawn:

1. The mean activity concentration of ${ }^{226} \mathrm{Ra},{ }^{232} \mathrm{Th}$ and ${ }^{40} \mathrm{~K}$ have been found to be $68.2,173.9$ and $490 \mathrm{~Bq} / \mathrm{kg}$ respectively. On the average, activity concentration of ${ }^{226} \mathrm{Ra},{ }^{232} \mathrm{Th}$ and ${ }^{40} \mathrm{~K}$ were found to be below recommended value.

2. The radium equivalent activity for most of the tiles samples used is less than the recommended value of $370 \mathrm{~Bq} / \mathrm{kg}$ set in by UNSCEAR (2000) report excluding PNT ceramic $(30 \times 30)$, NISPRO, Goodwill Vitrified, PNT Ceramics $(25 \times 40)$ tiles sample with a value of 391 . $10,784.95,749.15$ and $559.49 \mathrm{~Bq} / \mathrm{kg}$ respectively.

3. The absorbed dose rate in air was found to be in the ranged of 70.61-352.51 $\mathrm{nGyh}^{-1}$ with mean value of $169.22 \mathrm{nGyh}^{-1}$ which is higher than international value of $55 \mathrm{nGyh}^{-1}$ by factors of 3.2 and 2.1 according to UNSCEAR (1998) and $80 \mathrm{nGyh}^{-1}$ by UNSCEAR (2000) respectively.

4. The average value of $\mathrm{H}_{\text {ex }}$ and $\mathrm{H}_{\text {in }}$ are 0.95 and 1.14 respectively. The mean value of $\mathrm{H}_{\mathrm{ex}}$ is lower than unity as recommended by UNSCEAR (2000) while $\mathrm{H}_{\text {in }}$ is higher. It was also observed that PNT ceramic $(30 \times 30)$, NISPRO, Goodwill Vitrified and PNT Ceramics $(25 \times 40)$ have values higher that international reference value.

5. The result of annual effective dose rate show higher value in tile samples BN ceramic, PNT ceramic $(30 \times 30 \mathrm{~mm})$, BN ceramic, NISPRO, Goodwill Vitrified, and PNT ceramic $(25 \times 40)$ above recommended value of $1 \mathrm{mSv} / \mathrm{yr}$ as well as on the average value.

6. The mean value of gamma activity index is 1 and is still within the world recommended value and the Alpha Index (I $\alpha)$ is 0.34 . From the result above, it shows that the tiles sample such as PNT ceramic $(30 \times 30)$, NISPRO, Goodwill Vitrified and PNT Ceramics $(25 \times 40)$ should be monitored before usage for building purposes.

7. The higher values of NISPRO produced along Abuja-Kaduna express way could be attributed to the nature of the basement complex of the Pan-African Orogeny of the sourced raw material of the granitic rock materials. Goodwill vitrified and PNT ceramics $(25 \times 30 \mathrm{~mm})$ may be attributed to the marine transgression and regression of metamorphosed sediments from far and near granitic tectonically and highly dissolved rock minerals in and round the Atlantic Ocean in Lagos.

\section{Acknowledgements}

The researchers appreciate Covenant University Ota for the grants given to embark on this research for the safety of our nation through Research Management Center Grant Scheme Number: CUCRID/VC/17/ 
02/02/06-FS. Also, appreciation goes to Radiation Geophysics Research Group, Department of Physics, Covenant University Ota, for their scientific contribution to this work.

\section{References}

Ademola, J.A., Farai, I.P., 2006. Gamma Activity and Radiation Dose in Content of some Building Materials in Nigeria by Gamma Ray Spectrometry.

Ali, S., Tufail, M., Jamil, K., Ahmad, A., Klian, H.A., 1996. Gamma-ray activity and dose rate of brick samples from some areas of North West Frontier Province (NWFP), Pakistan. Sci. Total Environ. 187 (3), 247-252.

Amin, S.A., Naji, M., 2013. Natural radioactivity in different commercial ceramic samples used in Yemeni buildings. Radiat. Phys. Chem. 86, 37-41.

Baykara, O., Karatepe, S., Dogru, M., 2011. Assessments of natural radioactivity and radiological hazards in construction materials used in Elazig, Turkey. Radiat. Meas. 46, 153-158.

Beretka, J., Mathew, P.J., 1985. Natural radioactivity of Australian building materials, industrial waste sand by-products. HealthPhys 48, 87-95.

Damla, N., Cevik, U., Kobya, A.I., Celik, A., Celik, N., Yıldırım, I., 2011. Assessment of natural radioactivity and mass attenuation coefficients of brick and roofing tile used in Turkey. Radiat. Meas. 46, 701-708.

EC, 1999. Radiological protection principles concerning the natural radioactivity of building materials. Radiat. Prot. 112 .

Faheem, M., Mujahid, S.A., Matiullah, 2008. Assessment of radiological hazards due to the natural radioactivity in soil and building material samples collected from six districts of the Punjab province-Pakistan. Radiat. Meas. 43, 1443-1447.

Ghosh, D., Deb, A., Bera, S., Sengupta, R., Patra, K.K., 2008. Assessment of alpha activity of building materials commonly used in West Bengal, India. J. Environ. Radioact. 99 (2), 316-321.

IAEA. 1989. Technical Reports, Series No: 295, International Atomic Energy Agency.

Iqbal, M., Tufail, M., Mirza, S.M., 2000. Measurement of natural radioactivity in marble found in Pakistan using a NaI (Tl) gamma-ray spectrometer. J. Environ. Radioact. 51, 255-265.

International Atomic Energy Agency, 2003. Extent of Environmental Contamination by Naturally Occurring Radioactive Material (NORM) and Technological Options for Mitigation, Technical Reports Series No. 419, STI/DOC/010/419.

ICRP, 1994. Protection Against Rn-222 at Home and at Work. ICRP Publication 65, Ann ICRP, 23 (2), pp. 1-48.

Lu, X., 2005. Natural radioactivity in some building materials of Xi'an, China. Radiat. Meas. 40, 94-97.

OECD (Organization for Economic Co- operation and Development), 1979. Exposure to Radiation from Radioactivity in Building Materials. Report by a Group of Experts of The OECD Nuclear Energy Agency.

Righi, S., Bruzzi, L., 2006. Natural radioactivity and radon exhalation in building materials used in Italian dwellings. J. Environ. Radioact. 88, 158-170.

RPA, 2000. Naturally Occurring Radiation in the Nordic Countries: Recommendations Statens stralskyddsinstitut, Stockholm.

Tufail, M., Nasim, A., Sabiha, J., Tehsin, H., 2007. Natural radioactivity hazards of building bricks fabricated from soil of two districts of Pakistan. J. Radiol. Prot. 27, 481-492.

Turhan, S., Baykan, U.N., Sen, K., 2008. Measurement of the natural radioactivity in building materials used in Ankara and assessment of external doses. J. Radiol. Prot. 28 (1), 83-91.

Lu, X., Zhang, X., 2008. Radionuclide content and associated radiation hazards of building materials and by-products in Baoji, China. Radiat. Prot. Dosim. 128, 471-476.

UNSCEAR, 1998. Sources, Effects and Risks of Ionizing Radiations. United Nations, New York.

UNSCEAR, 2000. Sources, Effects, and Risks of Ionizing Radiation. Report to the General Assembly, with Scientific Annexes, UN, New York.

Xinwei, L., Lingqing, W., Xiaodan, J., Leipeng, Y., Gelian, D., 2006. Specific activity and hazards of Archeozoic-Cambrian rock samples collected from the Weibei area of Shaanxi, China. Radiat. Prot. Dosim. 118, 352-359. 